\title{
Use of calcareous algae and monensin in Nellore cattle subjected to an abrupt change in diet
}

\author{
Produto a base de algas calcárias e monensina na transição abrupta \\ para dietas com elevada proporção de concentrado para bovinos Nelore
}

\author{
Roberta Ferreira Carvalho ${ }^{I^{*}}{\text { Madeline Rezende } \text { Mazon }^{\mathrm{I}} \text { Ana Paula dos Santos Silva }}^{\mathrm{I}}$ \\ Leticia Silva Oliveira' Claiton André Zotti ${ }^{I}$ Saulo da Luz e Silva ${ }^{I}$ Paulo Roberto Leme ${ }^{\mathrm{I}}$
}

\section{ABSTRACT}

Additives are used in high concentrate diets to prevent metabolic disorders in cattle. This study was designed to evaluate the effect of calcium sources and monensin on the control of ruminal acidosis in Nellore cattle that were abruptly shifted to a high (92.3\%) concentrate diet. Eight cannulated steers were randomly assigned to two contemporary $4 \times 4$ Latin square. Treatments involved the addition of a calcium source, either limestone (LI) or a product derived from calcareous algae (CA), to the basic diet with or without the presence of monensin. Calcareous alga (Lithothamnium calcareum) is a natural and renewable product and a source of calcium carbonate. The quantity of added limestone, calcareous algae and monensin was $7.1 \mathrm{~g} \mathrm{~kg}^{-1}$, $7.4 \mathrm{~g} \mathrm{~kg}^{-1}$ and $30 \mathrm{mg} \mathrm{kg}^{-1} \mathrm{DM}$, respectively. There was no effect of calcium source $(P=0.607)$ or monensin $(P=0.294)$ on feed intake or on the concentration of short chain fatty acids. Treatments with calcareous algae resulted in a higher mean ruminal $\mathrm{pH}$ $(P=0.039)$, a shorter amount of time with the ruminal $\mathrm{pH}$ under 5.2 $(P<0.001)$ and a better control of blood $\mathrm{pH}(P=0.006)$. Treatments with monensin also resulted in a shorter amount of time with the ruminal pH below $5.2(P=0.023)$. Calcareous algae were shown to be effective in controlling adverse changes in the rumen and in blood variables for Nellore cattle that were subjected to an abrupt change to a high concentrate diet.

Key words: acidosis, feedlot, high concentrate, ruminal variables.

\section{RESUMO}

Os aditivos são amplamente utilizados em dietas com elevada proporção de concentrado a fim de prevenir distúrbios metabólicos em bovinos. Este estudo foi desenvolvido para avaliar o efeito das diferentes fontes de cálcio, com ou sem monensina sódica na dieta, no controle da acidose ruminal de bovinos Nelore, recebendo, de forma abrupta, uma dieta com elevada proporção (92,3\%) de concentrado. Oito bovinos portadores de cânulas ruminais foram distribuídos em um delineamento quadrado latino (4x4) duplo contemporâneo. Os tratamentos foram a adição de diferentes fontes de cálcio, calcário calcítico (LI) ou produto a base de alga calcária (CA), com (WIMO) ou sem (WOMO) a presença de monensina, à dieta base. A alga calcária, Lithothamnium calcareum, é um produto natural, renovável e fonte de carbonato de cálcio, podendo ser uma alternativa no controle desses distúrbios. A inclusão de LI, CA e monensina foi de 7,1 $\mathrm{g} \mathrm{kg}^{-1}, 7,4 \mathrm{~g} \mathrm{~kg}^{-1}$ e $30 \mathrm{mg} \mathrm{kg}^{-1} \mathrm{MS}$, respectivamente. Não houve efeito das fontes de cálcio e da monensina sobre o consumo alimentar e concentração total dos ácidos graxos de cadeia curta. Os tratamentos com AC resultaram em maior $p H$ ruminal médio $(P=0,039)$, menor tempo com $p H$ ruminal abaixo de 5,2 $(P<0,001)$ e um maior $p H$ sanguíneo $(P=0,006)$. Os tratamentos com monensina apresentaram menor tempo com $\mathrm{pH}$ ruminal abaixo de 5,2 $(P=0,023)$. O produto a base de alga calcária foi eficiente no controle das mudanças adversas das variáveis ruminais e sanguíneas em bovinos Nelore submetidos a mudanças abruptas para dietas com elevada proporção de concentrado.

Palavras-chave: acidose, alto concentrado, confinamento, variáveis ruminais.

\section{INTRODUCTION}

The increasing proportion of concentrates and extensive use of processed grains in feedlot diets enhance animal performance but increase the occurrence of metabolic disorders such as ruminal acidosis, the most prevalent condition affecting feedlots after respiratory diseases (VASCONCELOS \& GALYEAN, 2008). Feed additives can be used to improve the digestive efficiency of the diet, control fermentation and

IFaculdade de Zootecnia e Engenharia de Alimentos (FZEA), Universidade de São Paulo (USP), 13635-900, Pirassununga, SP, Brasil.

E-mail: robertacarvalho@usp.br. "Corresponding author. 
maintain a stable ruminal $\mathrm{pH}$. The use of additives has been widely studied (STOCK et al., 1995; MENEZES et al., 2006; ELLIS et al., 2012), and additives are in frequent use; however, the use of some antibiotics such as monensin and salinomycin has been banned by the European Union, intensifying the search for alternatives to decrease the risk of metabolic disorders.

The calcareous alga Lithothamnium calcareum is rich in calcium carbonate and magnesium, and it has some trace elements present in varying amounts, such as $\mathrm{Fe}, \mathrm{Mn}, \mathrm{B}, \mathrm{Ni}, \mathrm{Cu}, \mathrm{Zn}$, Mo, Se and Sr. This alga has highly bioavailable micronutrients in its cell wall, high porosity $(>40 \%)$ that allows for greater specific surface area (DIAS, 2000) and a good balance among polymorphs (calcite, vaterite, aragonite, dolomite), which maintains bioavailability regardless of $\mathrm{pH}$. Its use in agriculture (SOUZA et al., 2009) and animal nutrition has been studied (FARRAN et al., 2003; MELO et al., 2006), but little is known about its role in the control of ruminal $\mathrm{pH}$ in cattle transitioning between diets. Thus, the objective of this study was to evaluate the efficacy of feed additives during the abrupt shift from a diet that is strictly roughage to a high concentrate diet for feedlot cattle and compare the effect of calcium sources in the presence of the antibiotic monensin, which is often added to this type of diet.

\section{MATERIALS AND METHODS}

The research was conducted at the Animal Science Department of the Faculty of Animal Science and Food Engineering, Universidade de São Paulo (USP), in Pirassununga, SP. Eight Nellore steers with a body weight of approximately $550 \pm 65 \mathrm{~kg}$ were fitted with ruminal cannulas and were randomly assigned to one of four treatments. Animals were housed in individual stalls that were equipped with feeders and automatic water The study had a total duration of 156 days divided into four 24-day periods (day -3 to day 21); each period was separated by a 20-day interval in which the steers were fed only with hay and mineral salt.

Prior to the beginning of the experiment, the animals received a pure roughage diet ad libitum (Tifton hay) and mineral salt. On the first day (day 1) of the experimental diet, the animals were fed with a base diet (Table 1) containing 92.25\% concentrate and $7.75 \%$ roughage; this diet was fed daily at seven in the morning. Treatments involved the addition of a calcium source to the concentrate, either limestone (LI) (calcitic limestone, Iguatama, Brazil) or a product derived from calcareous algae (CA) (Top
Table 1 - Composition of diets with different sources of calcium expressed as a percentage of dry matter (DM).

\begin{tabular}{|c|c|c|}
\hline \multirow{2}{*}{ Ingredients (\%) } & \multicolumn{2}{|c|}{ 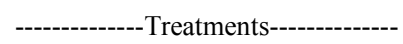 } \\
\hline & $\mathrm{CA}$ & LI \\
\hline Raw cane bagasse & 7.75 & 7.75 \\
\hline Corn grain (broken) & 82.38 & 82.37 \\
\hline Soybean meal & 6.78 & 6.78 \\
\hline Urea & 1.29 & 1.29 \\
\hline Mineral salt & 0.53 & 0.53 \\
\hline Potassium chloride & 0.53 & 0.53 \\
\hline Calcareous algae $^{1}$ & 0.74 & - \\
\hline Limestone & - & 0.71 \\
\hline \multicolumn{3}{|c|}{ Chemical composition (\% DM) - } \\
\hline $\mathrm{NDT}^{2}$ & 85.02 & 85.02 \\
\hline $\mathrm{CP}$ & 16.05 & 15.91 \\
\hline RDP (\%CP) & 48.30 & 48.30 \\
\hline MM & 2.91 & 2.83 \\
\hline NDF & 12.04 & 11.62 \\
\hline EE & 3.35 & 3.10 \\
\hline $\mathrm{Ca}$ & 0.36 & 0.36 \\
\hline$P$ & 0.37 & 0.37 \\
\hline
\end{tabular}

$\mathrm{CA}=$ calcareous algae, $\mathrm{LI}=$ limestone .

${ }^{1}$ Top buffer $^{\circledR}$ (Sanphar, Campinas, São Paulo, Brasil).

${ }^{2}$ Estimated using the methodology of WEISS et al. (1992).

buffer $^{\circledR}$ Sanphar, Campinas, Brazil), with or without the presence of monensin (MO) (Bovensin ${ }^{\circledR}$ Phibro, Guarulhos, Brazil). Quantity of LI, CA and MO added was $7.1 \mathrm{~g} \mathrm{~kg}^{-1}, 7.4 \mathrm{~g} \mathrm{~kg}^{-1}$ and $30 \mathrm{ppm}$, respectively. All diets were formulated to provide the same amount of calcium $(0.17 \%)$. The CA is a source of calcium, but it also contains tri-basic copper chloride and magnesium oxide.

Individual intake was adjusted daily to maintain $10 \%$ orts. The orts were weighed and sampled daily, and samples were combined at the end of each period and frozen for later analysis. The variation in dry matter intake was calculated for each animal as the difference in consumption between consecutive days following the start of the high concentrate diet.

Ruminal $\mathrm{pH}$ was recorded by a data logger (Model T7-1 LRCpH, Dascor, Escondido, CA) inserted into the rumen through the ruminal cannula and programmed to record the $\mathrm{pH}$ at five-minute intervals. The $\mathrm{pH}$ measurement was performed from the $3^{\text {rd }}$ day before the diet transition through the $21^{\text {st }}$ day of feeding the challenge diet. After this time period, the data logger was removed from the rumen, and the data were analyzed to determine the maximum $\mathrm{pH}$, average $\mathrm{pH}$, minimum $\mathrm{pH}$, time below 
$\mathrm{pH} 5.2$ and 5.6, and area below $\mathrm{pH} 5.2$ and 5.6. The area was calculated by multiplying the absolute value of $\mathrm{pH}$ deviations below the permanence time limit (min) for each measure (5.2 and 5.6) and was then converted to units of $\mathrm{pH} \times$ hours (MOYA et al. 2011).

Samples of rumen contents were collected from three different positions corresponding to the anterior, posterior and ventral bags, with the aid of a vacuum pump (Marconi MA 058, Piracicaba, Brazil), and were frozen immediately after collection for an analysis of short chain fatty acids, ammonia-N and lactic acid. Samples were collected six hours after feeding at days $-3,-1,1,2,4,7,14$ and 21 .

Analysis of short chain fatty acids was conducted via gas chromatography as recommended by ERWIN et al. (1961). Determination of NH3-N was performed according to the methodology described by CHANEY \& MARBACH (1962), and the total lactic acid concentration was determined by colorimetric analysis according to PRYCE (1969).

Venous blood samples were collected on day 1 (before diet shift) and on days 2, 8 and 15 (after diet shift). Blood samples were collected two hours after the diet was offered. Immediately after collection, the samples were analyzed using a portable automatic analyzer (iSTAT ${ }^{\circledR}$ Abbott, Rio de Janeiro, Brazil). For each sample, the $\mathrm{pH}$, carbon dioxide in the plasma bicarbonate, base excess, partial pressure of carbon dioxide, total carbon dioxide, partial pressure of oxygen and oxygen saturation were determined.

Data were analyzed using the mixed procedure for mixed models (SAS ${ }^{\circledR}$ Inst. Inc., Cary, NC) with all characteristics evaluated as repeated measures within a $4 \times 4$ Latin square design with a $2 \times 2$ factorial arrangement (calcium source $\mathrm{x}$ with/without monensin) and with treatments during four periods. In the statistical model, the calcium source, monensin presence, and the interaction of calcium source vs. presence of monensin were fixed effects, and time (days), period, animal and animal $\mathrm{x}$ treatment were random effects. When a significant effect $(\mathrm{P}<0.05)$ of the primary factors or interaction was observed, the means were compared using Tukey's test.

\section{RESULTS AND DISCUSSION}

There was no interaction between the calcium source and the presence of monensin for dry matter intake, ruminal $\mathrm{pH}$, ammonia- $\mathrm{N}$, lactate and blood variables.

The dry matter intake was not influenced $(\mathrm{P}=0.607)$ by the calcium source but was influenced by time $(\mathrm{P}<0.001)$; the animals showed a sharp drop in feed intake (from $2 \%$ to $1.3 \% \mathrm{LW}$ ) between the third and seventh day (Figure 1). This decrease can be explained by the low ruminal $\mathrm{pH}$, which adversely affects the feed intake of animals (DIJKSTRA et al., 2012).

There was an effect of calcium source on the control of ruminal $\mathrm{pH}$; treatments with $\mathrm{CA}$ showed a higher ruminal maximum $\mathrm{pH}(\mathrm{P}=0.029)$ and mean $\mathrm{pH}(\mathrm{P}=0.039)$, a shorter amount of time with the ruminal $\mathrm{pH}$ below $5.6(\mathrm{P}=0.034)$ and $5.2(\mathrm{P}=0.002)$ and a smaller area below $\mathrm{pH} 5.6(\mathrm{P}=0.014)$ and 5.2 $(\mathrm{P}=0.048)$ compared with the LI treatment (Table 2 ). The effect of CA on ruminal $\mathrm{pH}$ may be related to the slow release of calcium resulting from its polymorphic nature $(70 \%$ calcite, $1 \%$ vaterite, $17 \%$ aragonite, and $12 \%$ dolomite based on analysis by $\mathrm{x}$-ray diffraction), thereby prolonging its neutralizing action on ruminal $\mathrm{pH}$. A prolonged period of low ruminal $\mathrm{pH}$ may affect feed intake and decrease rumination, which could negatively affect animal performance (SCHWARZKOPF-GENSWEIN et al., 2003).

FARRAN et al. (2003) evaluated how the use of sodium bicarbonate, Rumensin and Acid Buf ${ }^{\circledR}$ (a product derived from calcareous algae) affects ruminal characteristics and feed intake of feedlot cattle and found similar results to those reported in this study. It was also observed that animals that received the Acid Buf ${ }^{\circledR}$ product showed higher maximum, medium and minimum $\mathrm{pH}$ values relative to the control, with an increase in the average $\mathrm{pH}$ from 5.95 to 6.12 . OLIVEIRA et al. (2003) also reported results similar to those found in this study when evaluating the effect of calcium carbonate, limestone or magnesium oxide on the control of ruminal $\mathrm{pH}$ of feedlot sheep. They reported higher ruminal $\mathrm{pH}$ values for sheep treated with calcium carbonate and attributed this effect to factors not evaluated by their study, such as rumination time, particle size and fiber content of the diet.

The blood $\mathrm{pH}(\mathrm{P}=0.0067)$ and base excess $(\mathrm{P}=0.0339)$ were higher for treatments with

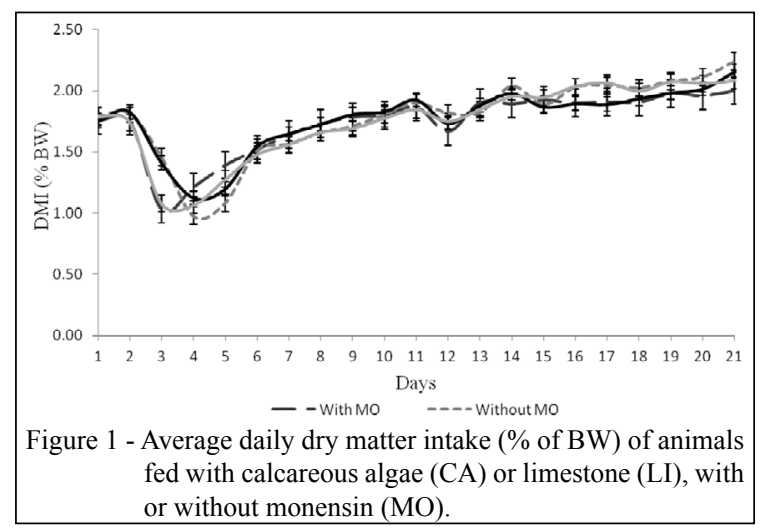

Ciência Rural, v.46, n.4, abr, 2016. 
Table 2 - Ruminal pH values of Nellore cattle that were fed diets with calcareous algae (CA) or limestone (LI), with or without monensin (MO).

\begin{tabular}{|c|c|c|c|c|c|c|c|c|c|}
\hline \multirow{2}{*}{ Variable } & \multicolumn{2}{|c|}{ Calcium Source } & \multirow{2}{*}{ SEM } & \multicolumn{2}{|c|}{-------Monensin------- } & \multirow{2}{*}{ SEM } & \multicolumn{3}{|c|}{ - } \\
\hline & $\mathrm{CA}$ & LI & & Without & With & & Calcium Source & MO & Calcium Source X MO \\
\hline \multicolumn{10}{|c|}{--------------------------------------------------------------------------------Ruminal pH-------------------------------------------------------------------------------- } \\
\hline Maximum & 6.77 & 6.84 & 0.02 & 6.76 & 6.85 & 0.02 & 0.029 & 0.008 & 0.445 \\
\hline Mean & 6.01 & 6.09 & 0.02 & 6.01 & 6.08 & 0.03 & 0.039 & 0.074 & 0.754 \\
\hline Minimum & 5.40 & 5.44 & 0.03 & 5.40 & 5.44 & 0.03 & 0.489 & 0.376 & 0.177 \\
\hline \multicolumn{10}{|c|}{-Time below (minutes) - } \\
\hline $\mathrm{pH} 5.2$ & 150 & 78 & 12.99 & 151 & 79 & 13.03 & $<0.001$ & 0.023 & 0.754 \\
\hline & & & & & a beloy & $\mathrm{H} \times \mathrm{hol}$ & & & \\
\hline pH 5.6 & 2.29 & 1.64 & 0.63 & 2.44 & 1.49 & 0.63 & 0.014 & 0.004 & 0.696 \\
\hline pH 5.2 & 0.60 & 0.33 & 0.09 & 0.67 & 0.40 & 0.09 & 0.048 & 0.025 & 0.310 \\
\hline
\end{tabular}

CA (Table 3). Other blood characteristics were not significantly different between treatments. Base excess refers to the difference between the concentration of the base and concentration of the acid in the intracellular fluid. Both treatments resulted in values within the normal range $(0 \pm$ $\left.2 \mathrm{mmol} \mathrm{L}^{-1}\right)$, but the treatment with the CA resulted in higher values (RADOSTITS et al., 2002). The effects of $\mathrm{CA}$ on blood $\mathrm{pH}$ and base excess are most likely related to its composition because CA contains magnesium oxide as well as calcium carbonate, both of which are alkalizing.

There are few studies where the effects of CA on blood characteristics have been evaluated. However, HA et al. (1983), when assessing buffering effects in lambs fed with a high concentrate diet, reported no effect of treatments on blood lactic acid concentration. WHEELER et al. (1981) also reported no difference in blood $\mathrm{pH}$ or bicarbonate when evaluating the effect of calcium levels and baking soda in high concentrate diets for beef cattle.

The addition of monensin did not affect blood characteristics, and these remained within the normal values reported by CARLSO (1997). According to OWENS et al. (1998), blood pH is relatively stable because it is regulated by very efficient buffering systems (including bicarbonate, phosphate, hemoglobin, ammonia and proteins). Based on the blood and ruminal characteristics found in our study, there was no metabolic acidosis in either treatment.

Neither the total concentration of short chain fatty acids, nor the acetate: propionate ratio was affected by the calcium source or the presence of monensin; there was also no effect on the concentrations of acetate, propionate, isobutyrate, valerate and lactate (Table 4). FARRAN et al. (2003)

Table 3 - Blood characteristics of Nellore cattle fed diets with limestone (LI) or calcareous algae (CA), with or without monensin (MO).

\begin{tabular}{|c|c|c|c|c|c|c|c|c|c|}
\hline \multirow{2}{*}{ Variable } & \multicolumn{2}{|c|}{----Calcium Source---- } & \multirow{2}{*}{ SEM } & \multicolumn{2}{|c|}{--------Monensin-------- } & \multirow{2}{*}{ SEM } & \multicolumn{3}{|c|}{ 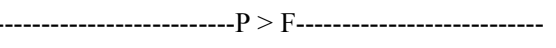 } \\
\hline & $\mathrm{CA}$ & LI & & Without & With & & Ca source & MO & Ca source $\mathrm{x} M O$ \\
\hline $\mathrm{pH}$ & 7.35 & 7.37 & 0.004 & 7.36 & 7.36 & 0.004 & 0.006 & 0.664 & 0.949 \\
\hline $\mathrm{pCO}_{2} \mathrm{mmHg}$ & 43.42 & 43.53 & 0.436 & 43.10 & 43.85 & 0.435 & 0.852 & 0.219 & 0.881 \\
\hline $\mathrm{BE} \mathrm{mmol} \mathrm{L}^{-1}$ & -1.13 & -0.03 & 0.372 & -0.70 & -0.47 & 0.371 & 0.033 & 0.661 & 0.992 \\
\hline $\mathrm{HCO}_{3} \mathrm{mmol} \mathrm{L}^{-1}$ & 24.30 & 25.09 & 0.319 & 24.61 & 24.79 & 0.319 & 0.073 & 0.679 & 0.599 \\
\hline $\mathrm{TCO}_{2} \mathrm{mmol} \mathrm{L}^{-1}$ & 25.44 & 26.27 & 0.331 & 25.69 & 26.01 & 0.331 & 0.471 & 0.071 & 0.826 \\
\hline $\mathrm{Lac}_{\mathrm{mmol} \mathrm{L}}^{-1}$ & 0.23 & 0.52 & 0.182 & 0.37 & 0.38 & 0.182 & 0.255 & 0.976 & 0.134 \\
\hline $\mathrm{pO}_{2} \mathrm{mmHg}$ & 32.29 & 32.13 & 0.460 & 32.23 & 32.18 & 0.460 & 0.791 & 0.947 & 0.723 \\
\hline $\mathrm{s}_{2} \%$ & 54.10 & 56.03 & 1.136 & 54.38 & 55.75 & 1.136 & 0.220 & 0.382 & 0.782 \\
\hline
\end{tabular}

$\mathrm{pH}$ : hydrogen potential, $\mathrm{pCO}_{2}$ : partial pressure of carbon dioxide, $\mathrm{BE}$ : base excess, $\mathrm{HCO}_{3}$ : bicarbonate, $\mathrm{TCO}_{2}$ : total carbon dioxide, Lac: lactate, $\mathrm{pO}_{2}$ : partial pressure of oxygen, $\mathrm{SO}_{2}$ : oxygen saturation.

Table 2 - Ruminal $\mathrm{pH}$ values of Nellore cattle that were fed diets with calcareous algae (CA) or limestone (LI), with or without monensin (MO). 
Table 4 - Average concentration of short chain fatty acids $(\mathrm{mM})$, lactate $(\mathrm{mM})$ and ammonia-N (mg dL $\left.\mathrm{dL}^{-1}\right)$ of Nellore steers fed diets with calcareous algae (CA) or limestone (LI), with or without monensin (MO). A:P = acetate and propionate ratio.

\begin{tabular}{|c|c|c|c|c|c|c|c|c|c|}
\hline \multirow{2}{*}{ Variable } & \multicolumn{2}{|c|}{---Calcium Source--- } & \multirow{2}{*}{ SEM } & \multicolumn{2}{|c|}{-------Monensin------- } & \multirow{2}{*}{ SEM } & \multicolumn{3}{|c|}{ 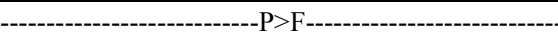 } \\
\hline & $\mathrm{CA}$ & LI & & Without & With & & Ca source & MO & Calcium Source x MO \\
\hline & & & & -Short ch & in fatty aci & $(\mathrm{mM})$ & ------------. & 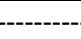 & --------------------------- \\
\hline Acetate & 55.14 & 55.14 & 2.16 & 56.17 & 54.11 & 2.16 & 0.999 & 0.501 & 0.230 \\
\hline Propionate & 22.76 & 22.76 & 1.04 & 23.33 & 22.19 & 1.04 & 1.000 & 0.441 & 0.743 \\
\hline Butyrate & 12.73 & 13.04 & 0.88 & 13.34 & 12.43 & 0.88 & 0.801 & 0.463 & 0.024 \\
\hline Isobutyrate & 1.11 & 1.11 & 0.05 & 1.13 & 1.08 & 0.05 & 0.995 & 0.498 & 0.120 \\
\hline Valerate & 1.32 & 1.31 & 0.07 & 1.38 & 1.25 & 0.07 & 0.894 & 0.173 & 0.121 \\
\hline Isovalerate & 3.07 & 3.07 & 0.27 & 3.04 & 3.01 & 0.27 & 1.000 & 0.878 & 0.050 \\
\hline SCFA total & 96.44 & 96.74 & 4.62 & 98.70 & 94.47 & 4.62 & 0.953 & 0.405 & 0.165 \\
\hline $\mathrm{A}: \mathrm{P}$ & 2.90 & 2.90 & 0.10 & 2.92 & 2.88 & 0.10 & 0.999 & 0.786 & 0.429 \\
\hline ammonia N (mg/dL) & 4.34 & 4.29 & 0.19 & 3.94 & 4.69 & 0.19 & 0.831 & 0.008 & 0.800 \\
\hline Lactate $(\mathrm{mM})$ & 0.97 & 0.85 & 0.16 & 1.05 & 0.77 & 0.16 & 0.603 & 0.214 & 0.886 \\
\hline
\end{tabular}

also reported no difference in the total concentration of short-chain fatty acids in response to calcium.

The source of calcium did not influence the ammonia-N concentration; treatments with $\mathrm{CA}$ and LI showed concentrations of 4.29 and $4.34 \mathrm{mg}$ $\mathrm{dL}^{-1}$, respectively. According to SANTOS (2006), the minimum concentration of ammonia-N for the production of microbial protein in diets with a high proportion of carbohydrate is 3.3 to $8.0 \mathrm{mg} \mathrm{dL}^{-1}$. Both treatments showed values adequate for proper microbial protein production.

According to CHEN \& RUSSELL (1989), monensin reduces the production of ammoniaby inhibiting gram positive bacteria (which specialize in ammonia metabolism), but contrary to expectations, monensin increased $(\mathrm{P}=0.008)$ the ammonia- $\mathrm{N}$ concentration in this study. Treatments with monensin had a mean ammonia-N concentration of $4.69 \mathrm{mg} \mathrm{dL}^{-1}$ compared with $3.94 \mathrm{mg} \mathrm{dl}^{-1}$ in treatments without monensin.

There was an interaction between calcium source and monensin with regard to the concentrations of butyrate and isovalerate. When added to the LI treatment, monensin resulted in a higher average concentration of butyrate (13.69 vs. $11.16 \mathrm{mM}$; $\mathrm{P}=0.024)$ and isovalerate $(3.48$ vs. $2.72 \mathrm{mM}, \mathrm{P}=0.05)$ compared with the LI treatment without MO (Table 4). However, when monensin was added to the treatment with $\mathrm{CA}$, the average concentration of butyrate and isovalerate was lower compared with the CA treatment without MO. Although these were significant differences, this interaction had no effect on the overall production of short chain fatty acids in the animal.

Monensin did not affect feed intake $(\mathrm{P}=0.2042)$; steers with or without monensin showed an average of 1.78 and $1.74 \% \mathrm{LW}$, respectively. Most studies report a reduction in feed intake with diets containing monensin (STOCK et al., 1995; DUFIELD et al., 2012); this additive generally increases energy availability of the feed.

All treatments were effective in controlling variables in the rumen during an abrupt transition from a strict roughage diet to a high concentrate diet, and the effects of calcareous algae were similar with or without monensin; calcareous algae, however, was a more effective buffering agent than calcium carbonate. Therefore, the inclusion of calcareous algae is a good alternative to facilitate the abrupt transition to high concentrate diets in Nellore steers.

\section{BIOETHICS AND BIOSSECURITY COMMITTE APPROVAL}

Process USP: 2012.1.876.74.0

\section{REFERENCES}

CARLSO, G.P. Fluid, eletrolyte, and acid-base balance. In: KANEKO, J.J. (Ed.). Clinical biochemistry of domestics animals. New York: Academic, 1997. p.485-516.

CHANEY, A.L.; MARBACH, E.P. Modified reagents for determination of urea and ammonia. Clinical Chemistry, v.8, n.2, p.130-162, 1962. Available from: <http://www.clinchem.org/ content/8/2/130.full.pdf + html $>$. Accessed: Jan. 28, 2014.

DIAS, G.T.M. Granulados bioclásticos - algas calcárias. Brazilian Journal of Geophysics, v.18, n.3, p.307318, 2000. Available: <http://dx.doi.org/10.1590/S0102261X2000000300008>. Accessed: Sept. 20, 2012. doi: 10.1590/ S0102-261X2000000300008.

DIJKSTRA, J. et al. Ruminal $\mathrm{pH}$ regulation and nutritional consequences of low $\mathrm{pH}$. Animal Feed Science and Technology, v.172, p.22-33, 2012. Available from: $<$ http://www. animalfeedscience.com/article/S0377-8401(11)00494-9/pdf $>$. Accessed: Jan. 30, 2014. doi: 10.1016/j.anifeedsci.2011.12.005. 
DUFIELD, T.F. et al. Meta-analysis of the effects of monensin in beef cattle on feed efficiency, body weight gain, and dry matter intake. Journal Animal Science, v.90, p.4583-4592, 2012. Available from: <https://www.animalsciencepublications.org/ publications/jas/articles/90/12/4583>. Accessed: Mar. 18, 2014. doi: $10.2527 /$ jas.2011-5018.

ERWIN, E.S. et al. Volatile fatty acid analyses of blood and rumen fluid gas chromatography. Journal of Dairy Science, v.44, n.9, p.1768-1771, 1961. Available from: <http://www. journalofdairyscience.org/article/S0022-0302(61)89956-6/pdf>. Accessed: Jan. 17, 2014. doi: 10.3168/jds.S0022-0302(61)89956-6.

FARRAN, T. et al. Evaluation of buffering agents in feedlot diets for cattle. Nebraska Beef Cattle Reports, p.34-38, 2003. Available from: $<$ http://digitalcommons.unl.edu/cgi/viewcontent.cgi?article=1 225\&context=animalscinbcr $>$. Accessed: May. 21, 2013.

HA, J.K.R. et al. In vitro effect of ph variations on rumen fermentation, and in vivo effects of buffers in lambs before and after adaptation to high concentrate diets. Journal Animal Science, v.56, p.698-706, 1983. Available from: $<$ https://www.animalsciencepublications.org/ publications/jas/abstracts/56/3/JAN0560030698>. Accessed: Mar. 17, 2014. doi: $10.2134 /$ jas $1983.563698 x$.

MELO, T.V. et al. Solubilidad in vitro de algunas fuentes de calcio utilizadas en alimentación animal. Archivos Zootecnia, v.55, n.211, p.297-300, 2006. Available from: $<$ http://www.redalyc.org/articulo. oa?id=49521110>. Accessed: Mar. 18, 2014.

MENEZES, L.F.G. et al. Perfil de ácidos graxos de cadeia longa e qualidade da carne de novilhos terminados em confinamento com diferentes níveis de monensina sódica na dieta. Ciência Rural, v.36, n.1, p.186-190, 2006. Available from: <http://dx.doi.org/10.1590/ S0103-84782006000100028>. Accessed: Jan. 20, 2014. doi: $10.1590 / \mathrm{S} 0103-84782006000100028$

MOYA, D. et al. Feeding behabior and ruminal acidosis in beef cattle offered a total mixed ration or dietary components separately. Journal Animal Science, v.89, p.520-530, 2011. Available from: $<$ https://www. animalsciencepublications.org/publications/jas/articles/89/2/520>. Accessed: Jan. 19, 2014. doi:10.2527/jas.2010-3045.

OLIVEIRA, E.R. et al. Estudo da eficiência do calcário calcítico, do carbonato de Cálcio e do óxido de magnésio no controle do $\mathrm{pH}$ ruminal. Revista Ciência Animal Brasileira, v.4, n.1, p.25-32, 2003. Available from: <http://www.revistas. ufg.br/index.php/vet/article/view/299>. Accessed: Jun. 08, 2014. doi:10.5216/cab.v4i1.299.

OWENS, F. et al. Acidosis in cattle: a review. Journal Animal Science, v.76, p.275-286, 1998. Available from: <https://www. animalsciencepublications.org/publications/jas/articles/76/1/275>. Accessed: Sept. 04, 2013. doi: /1998.761275x.
PRYCE, J.D. A modification of Barker-Summerson method for the determination of lactic acid. Analyst, v.94, p.11511152, 1969. Available from: <http://pubs.rsc.org/en/Content/ ArticleLanding/1969/AN/an9699401151\#!divAbstract $>$. Accessed: Jan. 29, 2013. doi: 10.1039/AN9699401151.

RADOSTITS, O.M. et al. Clinica veterinária. Um tratado de doenças dos bovinos. ovinos, suínos, caprinos e equinos. 9.ed. Rio de Janeiro. Ganabara Koogan, 2002. p.1770.

SANTOS, F.A.P. Metabolismo de proteínas. In: BERCHIELLI, T.T. et al. Nutrição de ruminantes. Jaboticabal: Funep, 2006. p.151-179.

SOUZA, H.A. et al. Avaliação de doses e produtos corretores da acidez em variáveis biométricas na produção de mudas de maracujazeiro. Acta Scientiarum. Agronomy, v.31, n.4, p.607612, 2009. Available from: <http://periodicos.uem.br/ojs/index. php/ActaSciAgron/article/view/529>. Accessed: Jan. 20, 2014. doi: 10.4025 /actasciagron.v31i4.529.

STOCK, R.A. et al. Effect of monensin and monensin and tylosin combination on feed intake variation of feedlot steers. Journal Animal Science, v.73, p.39-44, 1995. Available from: $<$ https:/www.animalsciencepublications.org/publications/jas/ articles/73/1/39>. Accessed: Sept. 25, 2013. doi: /1995.73139x.

SCHWARTZKOPF-GENSWEIN, K.S. et al. Effect of bunk management on feeding behavior, ruminal acidosis and performance of feedlot cattle: a review. Journal Animal Science, v.81, p.149-158, 2003. Available from: $<$ https://www.animalsciencepublications.org/ publications/jas/articles/81/14_suppl_2/E149>. Accessed: Sept. 26, 2013. doi: 2003.8114_suppl_2E149x.

VASCONCELOS, J.T;; GALYEAN, M.L. ASAS Centennial Paper: contributions in the Journal of Animal Science to understanding cattle metabolic and digestive disorders. Journal of Animal Science, v.86, p.1711-1721, 2008. Available from: $<\mathrm{https} / / \mathrm{www}$. animalsciencepublications.org/publications/jas/articles/86/7/0861711>. Accessed: Sept. 13, 2013. doi:10.2527/jas.2008-0854.

WEISS, W.P. et al. A therotically-based model for predicting total digestible nutrient values of forage and concentrates. Animal Feed Science and Technology, v.39, p.95-110, 1992. Available from: <http://www.sciencedirect.com/science/article/ pii/0377840192900344>. Accessed: Jan. 29, 2013. doi: 10.1016/0377-8401(92)90034-4.

WHEELER, W.E. et al. Effect of level of calcium and sodium bicarbonate in high concentrate diets on performance and nutrient utilization by beef steers. Journal of Animal Science, v.53, p.499-515, 1981. Available from: <https://www. animalsciencepublications.org/publications/jas/abstracts/53/2/ JAN0530020499>. Accessed: Jan. 26, 2014. doi:10.2134/ jas1981.532499x. 